\title{
Incentives and Work Ability on Job Satisfaction through Performance
}

\author{
Kasrul $^{1}$, Ali Murdhani Nngandoh ${ }^{\varpi_{2}}$ \\ 1PT Surveyor Indonesia (Persero) Pangkep \\ ${ }^{2}$ Sekolah Tinggi Ilmu Ekonomi (STIE) Amkop Makassar \\ DOI : https://doi.org/10.37531/ecotal.v1i1.4
}

\begin{abstract}
This type of research used in this research is associative research. The research location is at PT. Surveyor Indonesia in the Pangkep Region. The sample in this study used the census method where the entire population was sampled in the study as many as 57 employees. In conducting statistical tests using path analysis. The results showed that incentives have a positive and significant effect on job satisfaction at PT. Surveyor Indonesia in the Pangkep Region. Job ability has a positive and significant effect on job satisfaction at PT. Surveyor Indonesia in the Pangkep Region. Incentives have a positive and significant effect on performance. Work ability has a positive and significant effect on performance. Job satisfaction has a positive and significant effect on performance. Incentives have a positive and significant effect on performance through job satisfaction. Job ability has a positive and significant effect on performance through job satisfaction at PT. Surveyor Indonesia in the Pangkep Region.
\end{abstract}

\section{Keywords:}

Incentives, Work Ability, Job Satisfaction and Performance

\begin{abstract}
Abstrak : Jenis penelitian yang digunakan dalam penelitian ini adalah penelitian asosiatif. Lokasi penelitian berada di PT. Surveyor Indonesia di wilayah Pangkep. Sampel dalam penelitian ini menggunakan metode sensus dimana seluruh populasi dijadikan sampel dalam penelitian sebanyak 57 karyawan. Dalam melakukan pengujian statistik menggunakan analisis jalur. Hasil penelitian menunjukkan bahwa insentif berpengaruh positif dan signifikan terhadap kepuasan kerja pada PT. Surveyor Indonesia di wilayah Pangkep. Kemampuan kerja berpengaruh positif dan signifikan terhadap kepuasan kerja pada PT. Surveyor Indonesia di wilayah Pangkep. Insentif berpengaruh positif dan signifikan terhadap kinerja. Kemampuan kerja berpengaruh positif dan signifikan terhadap kinerja. Kepuasan kerja berpengaruh positif dan signifikan terhadap kinerja. Insentif berpengaruh positif dan signifikan terhadap kinerja melalui kepuasan kerja. Kemampuan kerja berpengaruh positif dan signifikan terhadap kinerja melalui kepuasan kerja pada PT. Surveyor Indonesia di wilayah Pangkep.
\end{abstract}

Kata Kunci : Insentif, Kemampuan Kerja, Kepuasan Kerja dan Kinerja

$\triangle$ Corresponding Author :

E-mail address: ali.murdhani@gmail.com (Mangasa, Kec. Makassar, Kota Makassar, Sulawesi Selatan)

“Received 03 December 2019, Accepted 07 January 2020, Published 20 January 2020" 


\section{Introduction}

The existence of humans in the company has a very vital position. The success of a corporate company is largely determined by the quality of the people who work in it. Rapid environmental changes require their ability to capture the phenomenon of change to analyze its impact on the company and prepare steps to deal with these conditions. Listen to the reality above the role of human resource management in the company is not just administrative, but rather more directed at how to be able to develop the potential of human resources to be creative and innovative.

According to (Kaleta \& Dorota, 2006:43) states that human resources are a very important factor in managing a company. This is needed so that the company can manage its company optimally so that it can support the achievement of a company's goals. The purpose of the organization, especially in corporate organizations can be profitability, maximizing shareholder value, minimizing risk and being accountable to many stakeholders. Basically, working people also want to earn money to make ends meet. For this reason, an employee starts to appreciate hard work and increasingly shows loyalty to the company and because of that the company rewards employee work performance by giving incentives. Incentive systems exist in almost every type of work from manual labor to professionals, managers and executive workers.

Jobs can provide job satisfaction for employees is work that feels fun to do work that is not fun to do is an indicator of dissatisfaction at work, job satisfaction functioned to be able to increase work morale, reduce absenteeism, increase loyalty and keep employees working at a company. Employees who get job satisfaction are employees who have a good level of attendance and work turnover, are passive in the union, and have better job performance than other employees. Furthermore, for employees who do not get job satisfaction will have an impact on the company in the form of employee absenteeism, job turnover, inaction in completing work, early resignation, active in the union, disrupted physical and mental health of its employees.

Performance phenomenon in PT. The Indonesian Surveyor in Pangkep Region still needs to be improved, especially the work ability of employees in terms of interacting to establish emotional relationships between employees in the form of communication, analyzing information both from within and from outside the organization and the ability to master equipment (technology) 
Kasrul $^{1}$, Ali Murdhani Nngandoh ${ }^{\otimes_{2}}$

in terms of employee effectiveness is still not maximized as well as targets in completing work both in time and volume, early resignation, being active in a union and are negative attitudes shown by employees in their work.

\section{Literature Review}

\subsection{Incentive}

Incentives are part of monetary rewards included in direct compensation whose payments are based on the performance of employees of a company. These incentives are given to employees to increase morale or work enthusiasm that will be able to improve their performance and ultimately increase company or organizational income. incentives refer to all of the concrete and moral methods that Jordanian travel and tourism institutions give in order to positively encourage the employees in a way that increase the production rate and enhance the employees' performance, which has its importance in satisfying the employees' desires and guarantee a loyal attitude towards the institution (Ashraf Mohammad Alfandi and Mohammad Shabieb Alkahsawneh, 2014). Anything that can attract an employee's attention and motivate them to work can be called as incentive (Smriti Chand). Incentive is a gift or appreciation given by a company to employees, clients, or consumers. The form can be in the form of money, tour packages or goods (Titus Indrajaya, 2015). An incentive mechanism is a treatment or measure that is used to motivate and encourage people (Irene Samari, 2019).

\subsection{Work ability}

Intellectual ability is the ability needed to carry out mental activities, for example thinking, analyzing and understanding. Good intellectual ability possessed by employees is expected to improve organizational intellectual. Based on the description above it can be concluded that what is meant by the ability of employees in this study are all the potential possessed by employees to carry out tasks based on knowledge, attitudes, experience, and education. Work ability is associated with nearly all factors of worklife, whether related to the individual, the workplace, or the immediate social environment or society (Raija Gould, Juhani Ilmarinen, Jorma Järvisalo and Seppo Koskinen, 2000). The foundation for work ability is an individual's health and functional capacity (Noone, J. H., Mackey, M.G., \& Bohle, P, 2014) The Work Ability Index (WAI) was developed to measure work ability and serve as a tool for investigating how long individuals are actually able to work, (Juhani Ilmarinen Mikaela von Bonsdorff, 2015). Work Ability is a comprehensive and contemporary approach to understanding and managing 
Kasrul $^{1}$, Ali Murdhani Nngandoh ${ }^{\otimes_{2}}$ Incentives and Work Ability on Job Satisfaction through Performance DOI : https://doi.org/10.37531/ecotal.v1i1.4

wellbeing in the workplace. Work Ability goes beyond traditional workplace interventions by assisting individuals to manage their own wellbeing, now and in the future, to make sure workers are able to work at their best and retire healthy (comcare.gov.au, 2013)

\subsection{The performance}

Performance is the result achieved by a person or group of people who do work with certain criteria and evaluated by certain parties as well. If related to the work process, it can be interpreted as a condition that shows the ability of an employee to carry out their duties in the office or place of work. According to (Rivai \& Sagala, 2003) suggested that: "Performance is a function of motivation and ability to complete one's tasks or work duly have a certain degree of willingness and level of ability. For performance management purposes, experienced practitioners agree that competencies should be defined in terms of important job behaviors and expectations that are associated with them (Elaine D. Pulakos, 2004). To perform is to take a complex series of actions that integrate skills and knowledge to produce a valuable result (Don Elger, 2017). In all of the research fields mentioned earlier, individual work performance is a relevant outcome measure of studies in the occupational setting (Linda Koopmans, Claire M. Bernaards, Vincent H. Hildebrandt, Wilmar B. Schaufeli, Henrica C.W. de Vet, and Allard J. van der Beek, 2011).

\subsection{Job satisfaction}

job satisfaction, researchers can conclude that job satisfaction is a positive attitude shown by employees towards their work, so employees can work happily without feeling burdened with the work and provide optimal results for the company. Job satisfaction is a crucial subject of attention which is very considered by the higher authorities, policy makers and top executives because this issue is related to many other significant and important issues of organisations (Wasif Ali, 2016). Job satisfaction refers to a person's feeling of satisfaction on the job which act as a motivation to work. It is not the self-satisfaction, happiness or self-contentment but the satisfaction on the job. Satisfaction does mean the simple feeling state accompanying the attainment by an impulse of its objective (Anju K J \& Mr.Sona George, 2011). Job satisfaction is closely related to the performance and quality of work performed by an employee and, consequently, translates into the success of an organization, because a satisfied employee builds and participates in the success of any organization (Barbara A. Sypniewska, 2013). Job satisfaction is an expression of one's feelings about welfare to do work, that job satisfaction is someone's attitude towards their work (Purwani Puji Utami, Herlyna, Alexius Dwi Widiatna, 
Kasrul $^{1}$, Ali Murdhani Nngandoh ${ }^{\otimes_{2}}$

Incentives and Work Ability on Job Satisfaction through Performance

DOI : $\underline{\text { https://doi.org/10.37531/ecotal.v1i1.4 }}$

Alpha Ariani and Faridah Karyati, 2020). Job satisfaction is a frequently studied variable in organizational behavior research, and also a central variable in both research and theory of organizational phenomena (Sri Langgeng Ratnasari, Gandhi Sutjahjo and Adam, 2020).

\section{Method, Data, and Analysi}

\subsection{Research Design}

Survey research design that is analyzing facts and data that support the information needed to support the discussion of research with this research approach is a quantitative approach.

\subsection{Sample Design}

Figure 1. PT. Surveyor Indonesia in the Pangkep Region

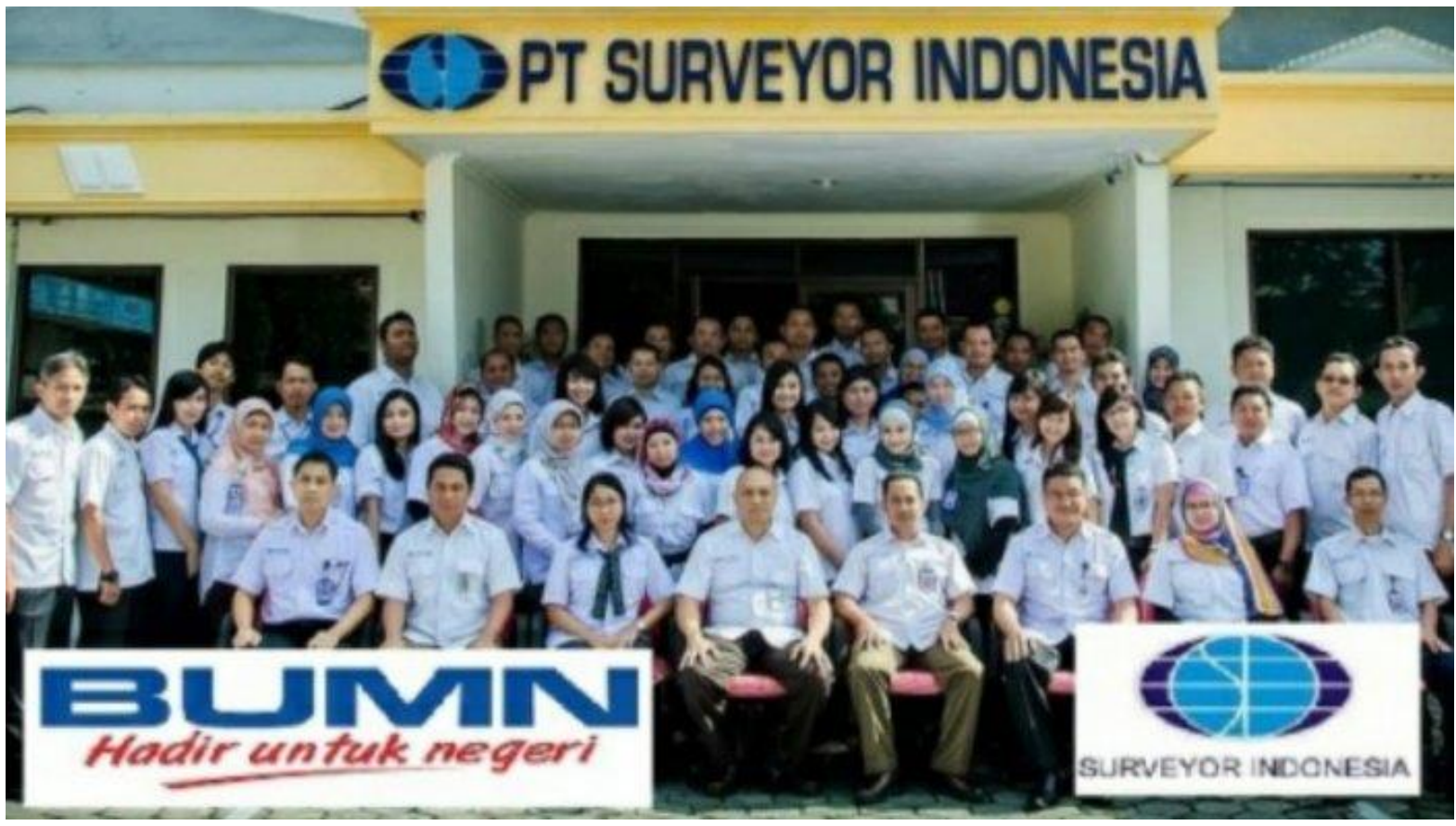

Source : File Document at PT. Surveyor Indonesia in the Pangkep Region

The location of the research site is PT. Surveyor Indonesia in the Pangkep Region, and this research was conducted for two months, from September to October 2019.

\section{Result and Discussion}

\subsection{Path Analysis}

This analysis is used to analyze the effect of various independent variables, namely compensation and discipline on one dependent variable, namely performance and intervening 
variables, namely work motivation, using Statistical Analysis with Path Analysis Analysis Model (Siswoyo Haryono and Parwoto, 2017).

According to (Abdurrahmat, Fathoni, 2006) the path analysis technique developed by Sewall Right is actually the development of a correlation technique that is broken down into several interpretations as a result. Path analysis has a closeness to multiple regression, so multiple regression is a special form of path analysis. This technique is known as a cause-and-effect model. This naming is based on the reason that path analysis allows researchers to test theoretical propositions regarding causal relations without manipulating variables.

Figure 2. Path analysis model

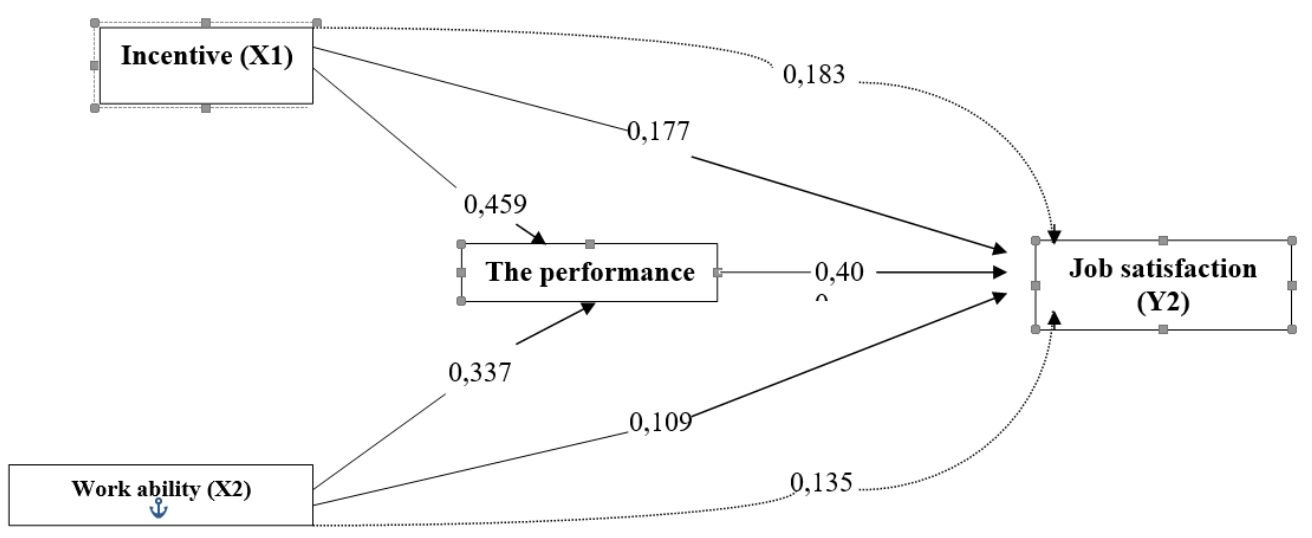

From the path analysis model, the path analysis equation formed is as follows:

Y1

Y1

Y2

Y2

$\mathrm{Y} 2=\mathrm{f}(\mathrm{X} 1, \mathrm{X} 2)$

$=\alpha 0+\alpha 1 X 1+\alpha 2 X 2+\mathrm{e} 1$

$=f(X 1, X 2, Y 1)$

$=\beta 0+\beta 1 X 1+\beta 2 X 2+\beta 3 Y 1+e 2$

$=\beta 0+\beta 1 X 1+\beta 2 X 2+\beta 3 Y 1(\alpha 0+\alpha 1 X 1+\alpha 2 X 2+\mathrm{e} 1)+\mathrm{e} 2$

Where : 


\section{Y1}

Y2

$\alpha 0 ; \beta 0$

\section{X1}

X2

$\alpha 1, \alpha 2, \beta 1, \beta 2, \beta 3$

e1, e2 = Performance

$=$ Job satisfaction

$=$ Constant

$=$ Incentive

$=$ Work ability

= Regression line coefficient

$=$ Error or confounding variable

\subsection{Effect of Incentives on Performance}

From the results of hypothesis testing, it shows that the incentives have a positive and significant effect on the performance of surveyor employees. This can be seen from the calculated $t$ value for the Incentives variable towards job satisfaction obtained by 3,718 with a significance price of 2,006. 0.05 because the value of $t$ arithmetic 3.718 is greater than the value of $t$ table 2.006 on the performance of employees at PT. Surveyor of Indonesia in the Pangkep Region. This shows that if incentives are worthy then performance will increase, and vice versa if incentives are not worthy of incentives then performance will also be low.

\subsection{Effect of Work Ability on Performance}

From the results of testing the hypothesis shows that work ability has a positive and significant effect on the performance of surveyor employees, it can be seen from the calculated $t$ value for the variable work ability to work satisfaction obtained by 2.733 with a significance price of 2.006 indicating that the value of $t$ obtained is significant because the significance price obtained less than 0.05 because the value of $t$ arithmetic 3.718 is greater than the value of $t$ table 2.006 on the performance of employees at PT. Surveyor of Indonesia in the Pangkep Region. This shows 
Kasrul $^{1}$, Ali Murdhani Nngandoh ${ }^{\otimes_{2}}$ Incentives and Work Ability on Job Satisfaction through Performance DOI : https://doi.org/10.37531/ecotal.v1i1.4

that if the ability to work is high, the performance will increase, and vice versa, if the ability to work is low, then the performance will also be low.

\subsection{Effect of Incentives on Job Satisfaction}

From the results of hypothesis testing shows that the incentives have a positive and significant effect on job satisfaction of surveyor employees. It can be seen from the t-value for the Incentive variable to Job satisfaction obtained by 2.168 with a significance price of 2.006 indicating that the value of $t$ obtained is significant because the significance price obtained is less of 0.05 because the value of $t$ count 2.168 is greater than the value of $t$ table 2.006 on the performance of employees at PT. Surveyor of Indonesia in the Pangkep Region. This shows that if incentives are worthy then job satisfaction will increase, and vice versa if incentives are not worthy of incentives then job satisfaction will also be low.

\subsection{Effect of Work Ability on Job Satisfaction}

From the results of hypothesis testing shows that work ability has a positive and significant effect on the performance of surveyor employees, it can be seen from the calculated $t$ value for the variable work ability to work satisfaction obtained by 2.170 with a significance price of 2.006 indicating that the value of $t$ obtained is significant because the significance price obtained less than 0.05 because the value of $t$ count 2.170 is greater than the value of $t$ table 2.006 on the performance of employees at PT. Surveyor of Indonesia in the Pangkep Region. this shows that if the ability to work is high, the performance will increase, and vice versa, if the ability to work is low, then the performance will also be low.

\subsection{Effect of Performance on Job Satisfaction}

From the results of hypothesis testing shows that work ability has a positive and significant effect on the performance of surveyor employees. It can be seen from the calculated $t$ value for the variable work ability to work satisfaction obtained by 2.685 with a significance price of 2.006 indicating that the value of $t$ obtained is significant because the significance price obtained less than 0.05 because the value of $t$ count 2.685 is greater than the value of $t$ table 2.006 on the performance of employees at PT. Surveyor of Indonesia in the Pangkep Region. This shows that if the ability to work is high, the performance will increase, and vice versa, if the ability to work is low, then the performance will also be low. 


\subsection{Effect of Incentives on Job Satisfaction Through Performance}

From the results of testing the hypothesis of the effect of incentives on job satisfaction through performance, this can be seen from the direct effect of 0.177 while the indirect effect of 0.183 . This shows that the effect of incentives on job satisfaction through performance is a positive and significant effect, this shows that if proper incentives received by employees, the performance will also increase, so job satisfaction of employees of PT. Surveyors for the Pangkep Region in Indonesia will increase.

\subsection{Effect of Work Ability on Job Satisfaction Through Performance}

From the results of testing the hypothesis of the effect of work ability on job satisfaction through performance, this can be seen from the direct effect of 0.109 while the indirect effect of 0.135 . This shows that the effect of work ability on job satisfaction through performance is a positive and significant effect, this shows that the higher the work ability of employees, the performance will also increase, so that the job satisfaction of employees of PT. Surveyors for the Pangkep Region in Indonesia will increase.

\section{Conclusion}

a) Incentives have a positive and significant effect on employee performance at PT. Surveyor of Indonesia in Pangkep Region.

b) Work ability has a positive and significant effect on employee performance at PT. Surveyor of Indonesia in Pangkep Region.

c) Incentives have a positive and significant effect on employee performance at PT. Surveyor of Indonesia in Pangkep Region.

d) Work ability has a positive and significant effect on employee job satisfaction at PT. Surveyor of Indonesia in Pangkep Region.

e) Performance has a positive and significant effect on employee job satisfaction at PT. Surveyor of Indonesia in Pangkep Region.

f) Incentives have a positive and significant effect on job satisfaction through employee performance at PT. Surveyor of Indonesia in Pangkep Region.

g) Work ability has a positive and significant effect on job satisfaction through employee performance at PT. Surveyor of Indonesia in Pangkep Region. 
Kasrul $^{1}$, Ali Murdhani Nngandoh ${ }^{\otimes_{2}}$

\section{References :}

Abdurrahmat, Fathoni. 2006. Research Methodology \& Thesis Preparation Techniques. Jakarta: PT Rineka Cipta.

Alfandi, Ashraf Mohammad and Mohammad Shabieb Alkahsawneh. The Role of the Incentives and Reward System in Enhancing Employee's Performance "A Case of Jordanian Travel and Tourism Institutions". International Journal of Academic Research in Business and Social Sciences, April 2014, Vol. 4, No. 4.

Ali, Wasif. Understanding the Concept of Job Satisfaction, Measurements, Theories and its Siginificance int the Recent Organizational Environment: A Theoretical Framework. Archives of Business Research-Vol.4, No.1.

Anju K J \& Mr.Sona George. A Study on Job Satisfaction of Employees in Bpcl - Kochi Refinery Limited, Ambalamugal. Conference Paper, 2011.

Chand, Smriti. Incentives: Meaning, Definition and Other Details. https://www.yourarticlelibrary.com/human-resource-development/incentivesmeaning-definition-and-other-details/32364.

comcare.gov.au. Australian Government Comcare. WHS 109 August 2013.

Elger, Don. Theory of Performance. Expectations of Faculty in Higher Education. https://www.webpages.uidaho.edu/ele/scholars/Results/Workshops/Facilitators_I nstitute/Theory\%20of\%20Performance.pdf

Haryono, S., \& Wardoyo, P. (2017). Structural Equation Modeling (SEM) for Management Research with AMOS 18.00. Jakarta: Luxima Metro Media.

Indrajaya, Titus. Potensi Industri Mice (Meeting, Incentive, Conference And Exibition) di Kota Tangerang Selatan, Provinsi Banten. Jurnal Ilmiah WIDYA, Volume 3 Nomor 2 September - Desember 2015, 80 - 87.

Juhani Ilmarinen Mikaela von Bonsdorff.(2014). Work Ability. Wiley Online Library. https://doi.org/10.1002/9781118521373.wbeaa254

Kaleta, Dorota (2006). Lifestyle Index and Work Ability. International Journal of Occupational Medicine and Environmental Health. 19 (3): 43.

Koopmans, Linda dkk. Conceptual Frameworks of Individual Work Performance. American College of Occupational and Environmental Medicine, JOEM Volume 53, Number 8, August 2011.

Noone, J. H., Mackey, M.G., \& Bohle, P. (2014). Work ability in Australia-pilot study: A report to Safe Work Australia. Canberra: Safe Work Australia.

Pulakos, Elaine D. Performance Management : A Roadmap for Developing, Implementing and Evaluating Performance Management Systems. SHRM Foundation Board: Madison, 2004.

Purwani Puji Utami dkk. Job Satisfaction And Work Productivity: An Empirical Approach. A Multifaceted Review Journal in the Field of Pharmacy, Sys Rev Pharm 2020;11(12):1243-1249.

Raija Gould. Dimensions of Work Ability Helsinki 2008 : Results of the Health 2000 Survey. Terveys Halsa Health : Finland, 2000.

Rivai. (2008). Human Resources Management for Companies. PT. Raja Grafindo Persada: Jakarta.

Samiri, Irene. Incentive Mechanisms of Human Resource Management (HRM) in Private Academic Institutions in Ghana. International Journal of Managerial Studies and Research

Volume 1 Issue 1 (2020)

Economics and Digital Business Review

ISSN: 2774-2563 (Online) 
(IJMSR), Volume 7, Issue 2, Febuary 2019, PP 28-38, http://dx.doi.org/10.20431/2349-0349.0702005.

Sri Langgeng Ratnasari dkk. The Effect of Job Satisfaction, Organizational Culture, and Leadership on Employee Performance. Annals of Tropical Medicine \& Public Health. September 2020 Vol. 23 Issue13A, http://doi.org/10.36295/ASR0.2020.231329.

Sypniewska ,Barbara A. Evaluation of Factors Influencing Job Satisfaction. Econsto : Make Your Publications Visible. http://dx.doi.org/10.5709/ce.1897-9254.131. 